\title{
Attenuated processing of proglucagon and glucagon-like peptide-1 in carboxypeptidase E-deficient mice
}

\author{
L Friis-Hansen, K A Lacourse ${ }^{1}$, L C Samuelson ${ }^{1}$ and J J Holst ${ }^{2}$ \\ Department of Clinical Biochemistry, Rigshospitalet, DK-2100 Copenhagen, Denmark \\ ${ }^{1}$ Department of Physiology, University of Michigan, Ann Arbor, Michigan 48109-0622, USA \\ ${ }^{2}$ Department of Physiology, The Panum Institute, DK-2200 Copenhagen, Denmark \\ (Requests for offprints should be addressed to L Friis-Hansen, Department of Clinical Biochemistry, KB-3014 Rigshospitalet, 9 Blegdamsvej, \\ DK-2100 Copenhagen, Denmark; Email: Ifh@rh.dk)
}

\begin{abstract}
The maturation of many peptide hormones is attenuated in carboxypeptidase E (CPE)-deficient fat/fat mice, leading to a slowly developing, adult-onset obesity with mild diabetes. To determine the contribution of the hormones generated from the proglucagon precursor to this phenotype, we studied the tissue-specific processing of glucagon and glucagon-like peptide-1 (GLP-1) in these mice. In all tissues examined there was a great reduction in mature
\end{abstract}

amidated GLP-1. Furthermore, a lack of CPE attenuates prohormone convertase processing of proglucagon in both the pancreas and the intestine. These findings suggest that defects in proglucagon processing together with other endocrine malfunctions could contribute to the diabetic and obesity phenotype in fat/fat mice.

Journal of Endocrinology (2001) 169, 595-602

\section{Introduction}

The $C P E^{\text {fat }}$ mouse strain (fat) exhibits a slowly developing adult-onset obesity with mild diabetes due to a spontaneous genetic mutation (Ser202Pro) in carboxypeptidase E (CPE) (Naggert et al. 1995), which abolishes enzyme activity and impair routing of CPE to the secretory granules (Varlamov et al. 1997). CPE removes C-terminal basic residues exposed after endoproteolytic processing of the prohormone precursor by the prohormone convertases (PCs). In all of the endocrine tissues examined so far, removal of C-terminal basic residues of peptide hormones has been attenuated in the fat/fat mice, but the overall response to the defect varies. Some endocrine systems respond by increasing the concentration of prohormone to maintain normal concentrations of the mature hormone, thus compensating for the attenuation in peptide hormone processing. Increased prohormone synthesis has been shown for insulin (Naggert et al. 1995), gastrin, (Lacourse et al. 1997, Udupi et al. 1997) and endocrine cholecystokinin (CCK) peptides (Cain et al. 1997, Lacourse et al. 1998). In other endocrine systems, there are no compensatory increases in hormone synthesis resulting in decreased concentrations of mature peptide hormone, as seen for dynorphin, neurotensin, melaninconcentrating hormone (Rovere et al. 1996) proopiomelanocortin (POMC) (Cool et al. 1997), substance P (Perloff et al. 1998) and neuronal CCK (Cain et al. 1997, Lacourse et al. 1998). Furthermore, Loh and co-workers have suggested that $\mathrm{CPE}$ could also act as a sorting receptor for insulin and POMC, and that loss of CPE is followed by a shift from regulated to constitutive hormone secretion (Cool et al. 1997, Normant \& Loh 1998, Rindler 1998).

Proglucagon is a neuroendocrine peptide hormone precursor with a very tissue-specific processing pattern (for a review, see Holst 1997). In the pancreatic $\alpha$-cells, proglucagon is processed to yield glucagon and the major proglucagon fragment (MPGF) (see Fig. 1). In intestinal L cells and neurons, proglucagon processing results in the liberation of glicentin, glucagon-related polypeptide (GRPP), oxyntomodulin, glucagon-like peptide-1 (GLP-1), intervening peptide-2 (IP-2) and glucagon-like peptide-2 (GLP-2) (see Fig. 1). Glucagon is an important regulator of glucose metabolism, having effects grossly opposing those of insulin. Gut GLP-1 is one of the incretin hormones and lowers blood glucose by several mechanisms: it stimulates insulin secretion in a glucose-dependent manner; it confers glucose sensitivity to $\beta$-cells; it inhibits glucagon secretion; and it slows gastric emptying. GLP-1 in the brain has been shown to be involved in the regulation of satiety (Tang-Christensen et al. 1996, Turton et al. 1996). Recent research points to GLP-2 as being one of the regulators of small-intestinal growth (Drucker et al. 1996).

The tissue-specific processing of glucagon is achieved by tissue-specific expression of prohormone convertases. Prohormone convertase (PC) 2 is important for the 

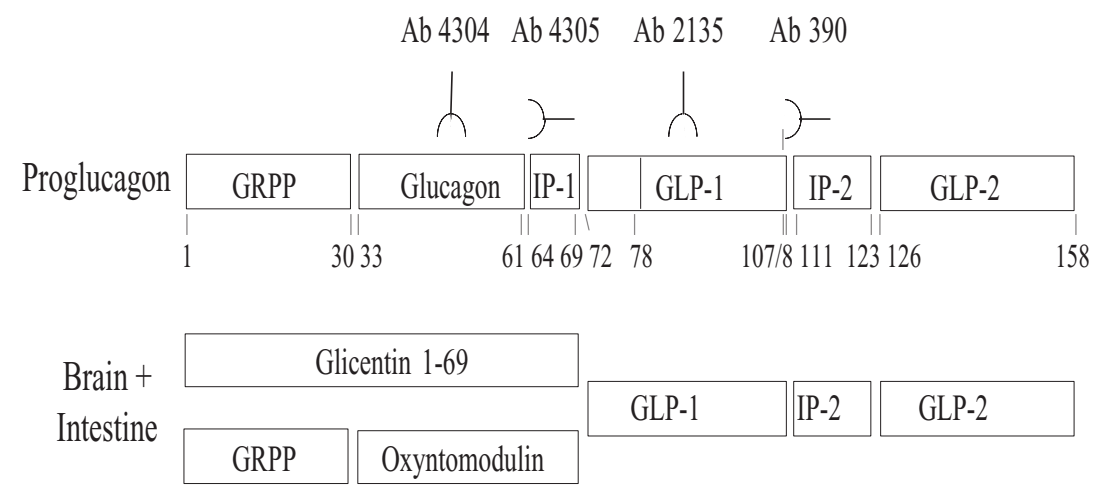

\begin{tabular}{c|l|l|l|l|l|}
\hline Pancreas & GRPP & Glucagon & IP-1 & \multicolumn{3}{|c|}{ MPGF } \\
\hline
\end{tabular}

Figure 1 The upper part of the figure shows the structural organisation of mouse proglucagon, with indications of the amino acid numbers (after the signal peptide has been cleaved off). The binding sites for antibodies (Ab) 390, 2135, 4304 and 4305 are also shown (see Materials and Methods). Shown below are the two different processing patterns of proglucagon. In the pancreas, processing of proglucagon primarily results in the liberation of glucagon and the major proglucagon fragment (MPGF). The aberrant pancreatic processing pattern, leading to the formation of glicentin 1-61, IP-1, GLP-1, IP-2 and GLP-2, is shown inside the dotted lines Proglucagon processing in the brain and gut mainly produces glicentin, oxyntomodulin, GLP-1, GLP-2 and IP-2. Glicentin always includes the glucagon and GRPP sequence but is found both with (glicentin 1-69) and without the IP-1 sequence (glicentin 1-61).

maturation of glucagon, supported by the attenuated glucagon processing in mice lacking PC2 or 7B2 (Furuta et al. 1997, Westphal et al. 1999). (7B2 is a neuroendocrine protein required for activation of $\mathrm{PC} 2$; a lack of $7 \mathrm{~B} 2$ renders PC2 inactive (Westphal et al. 1999).) PC1/3 alone may be the enzyme responsible for liberating GLP-1 and -2 (Rouille et al. 1995, 1997). Cleavage by PC1/3 or PC2 leaves one or two basic residues at the $\mathrm{C}$-terminus of the newly formed peptide, and these are subsequently removed by a carboxypeptidase. In the case of GLP-1, this removal is a prerequisite for carboxyamidation (Fig. 2). To date, the importance of amidation of GLP-1 is not fully understood, but it is believed that it might slow degradation of the hormone. Prohormone convertase cleavage of proglucagon also leaves basic amino acids at the C-terminus of glucagon, oxyntomodulin, glicentin,

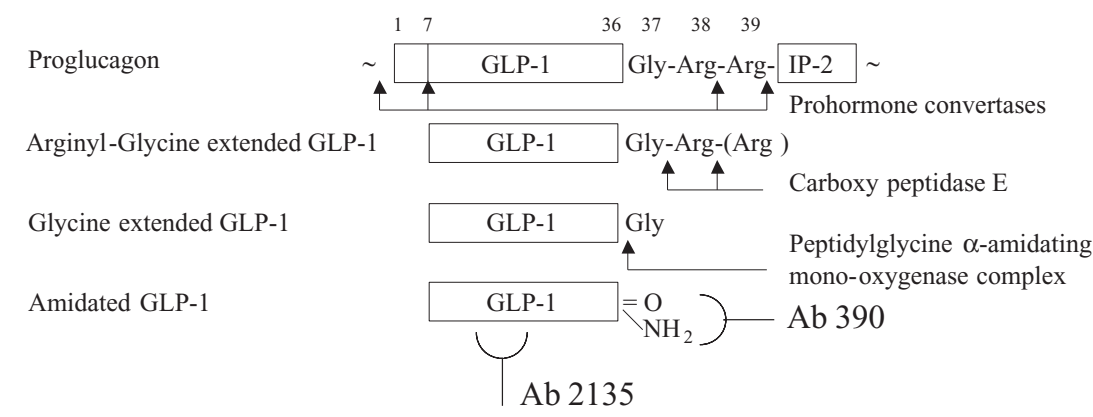

Figure 2 The figure shows the post-translational processing steps leading to the formation of amidated GLP-1. After endopeptilytic cleavage by the prohormone convertases, carboxypeptidases such as CPE cleave the C-terminal arginine from the arginyl-glycine extended GLP-1. This then allows the glycine to be used as the amide donor in the amidation process. The numbers refer to the amino acid numbers in proGLP-1. The binding sites for Ab 390 and Ab 2135 are also shown (see Materials and Methods). 
intervening peptide-1 (IP-1) and IP-2, all of which are subject to removal by a carboxypeptidase.

Given the involvement of glucagon and GLP-1 in both glucose metabolism and food intake, and their possible contribution to the obesity phenotype, we studied the processing and maturation of these hormones in fat/fat mice to establish the importance of $\mathrm{CPE}$ in vivo in proglucagon processing.

\section{Materials and Methods}

\section{Mice and genotyping}

Heterozygous fat/+ mice were purchased from The Jackson Laboratory (Bar Harbor, ME, USA). Mice were kept with a ratio of $12 \mathrm{~h}$ light: $12 \mathrm{~h}$ darkness and were allowed to feed ad libitum on Purina 5008 chow (Purina Mills Inc., Richmond, IN, USA). Homozygous fat/fat and wild-type $(+/+)$ mice were generated by intercrossing heterozygotes and were subsequently identified by genotyping the offspring by using an allele-specific PCR assay (Lacourse et al. 1997) on genomic DNA prepared from tail biopsies (Miller et al. 1988).

\section{Tissue isolation and extraction}

Adult mice 2-6 months old were anaesthetised, and the brains, pancreases, stomachs, small intestines and colons were rapidly dissected, washed gently in ice-cold PBS and frozen in liquid nitrogen (Danish Animal Ethical Committee approval no. 1998-56-84). To extract the peptides, the tissues were boiled in 5-10 volumes distilled water, homogenised using a Polytron homogeniser (Kinematica, Lucerne, Switzerland) and centrifuged at $10000 \mathrm{~g}$. The supernatants were collected and the pellets were re-extracted in $750 \mu \mathrm{l} 1 \mathrm{M} \mathrm{CH}_{3} \mathrm{COOH}$ and left at $4{ }^{\circ} \mathrm{C}$ for $1 \mathrm{~h}$, after which the extracts were centrifuged again at $10000 \mathrm{~g}$. The acidic supernatants were collected, pooled with the neutral supernatant and then stored at $-20{ }^{\circ} \mathrm{C}$. Before further analysis, the extracts were loaded onto SepPak C18 cartridges (Waters, Milford, MA, USA), which were activated according to the manufacturer's instructions and eluted with $70 \%(\mathrm{v} / \mathrm{v})$ ethanol containing $0 \cdot 1 \%$ trifluoroacetic acid. After evaporation in a vacuum centrifuge, the eluates were reconstituted in assay buffer (PBS supplemented with $0 \cdot 1 \%$ human serum albumin and $0.6 \mathrm{mmol} / 1$ thiomesal). Half of the reconstituted extract for each tissue was subjected to RIA as described below, and the remaining extracts were pooled and subjected to chromatography.

\section{Chromatography}

Pools $(n=4-6)$ of pancreatic or small-intestinal extracts were applied to Sephadex G-50 (Pharmacia, Uppsala,
Sweden) superfine columns $(16 \times 1000 \mathrm{~mm})$, which were eluted at $4{ }^{\circ} \mathrm{C}$ with sodium phosphate buffer $(\mathrm{pH} 7 \cdot 4)$ containing $0 \cdot 1 \%$ human serum albumin. Fractions of $1 \cdot 0 \mathrm{ml}$ were collected at a rate of $4.0 \mathrm{ml} / \mathrm{h}$.

The columns were calibrated with ${ }^{125}$ I-labelled albumin, to determine the void volume $\left(\mathrm{v}_{0}\right)$, and with ${ }^{22} \mathrm{NaCl}$, to determine the total available volume $\left(\mathrm{v}_{\mathrm{t}}\right)$. Subsequently, the elution constants $\left(\mathrm{k}_{\mathrm{d}}\right)$ were calculated as $\mathrm{k}_{\mathrm{d}}=\left(\right.$ fraction no. $\times$ volume of the fractions $\left.-\mathrm{v}_{0}\right) / \mathrm{v}_{\mathrm{t}}$. The columns were calibrated with synthetic GLP-1, glucagon, glicentin and oxyntomodulin, which yielded slender peaks at the expected positions. The eluted fractions were analysed with sequence-specific RIAs as described below.

\section{Radioimmunoassay}

Four different RIA assays were employed. An assay for the C-terminus of glucagon, using the antibody $(\mathrm{Ab}) 4305$ (Holst 1982). This antibody has an absolute requirement for the intact $\mathrm{C}$-terminus of the glucagon molecule, and therefore does not react with C-terminally elongated forms, including oxyntomodulin or glicentin. The standards used were human glucagon and tracer ${ }^{125}$ I-labelled human glucagon. The detection limit was below $1 \mathrm{pmol} / 1$ and the intra-assay coefficient of variation was below $5 \%$.

A 'side-viewing' glucagon assay was based on Ab 4304, which reacts with a mid-region (residues 6-15) of the glucagon sequence (Holst 1982). This antibody binds all molecular forms of glucagon and proglucagon (including glicentin and oxyntomodulin) with equal strength, regardless of modifications of the termini, and therefore provides a measure of the total amounts of glucagon and proglucagon. Assay conditions were as for the C-terminal assay. The detection limit was $5 \mathrm{pmol} / 1$ and the intra-assay coefficient of variation was below $6 \%$.

The assay for the amidated C-terminus of GLP-1 was based on Ab 390 (Ørskov et al. 1994), which has an absolute requirement for this region and reacts with neither the shortened nor the elongated molecular form, or with non-amidated, glycine-extended GLP-1 (GLP-1 7-37) or proglucagon 78-108. The standards used were human GLP-1, and monoiodinated ${ }^{125}$ I-labelled GLP-1 was used as the tracer. The detection limit was $1 \mathrm{pmol} / 1$ and the intra-assay coefficient of variation was $5 \%$.

The 'side-viewing' GLP-1 assay was based on Ab 2135, which reacts with a mid-region of the GLP-1 sequence (Ørskov et al. 1991). This antibody binds all molecular forms of GLP-1 with equal strength, regardless of modifications of the termini, and therefore provides a measure of the total amount of GLP-1-containing molecules. Assay conditions were as for the $\mathrm{C}$-terminal assay. The detection limit was $5 \mathrm{pmol} / 1$ and intra-assay coefficient of variation was $6 \%$. 
Table 1 Tissue concentrations of amidated GLP and of total proglucagon product measured by RIA in five different tissues in wild-type $(n=5)$ and fat/fat mice $(n=4)$. The values (means \pm S.E.M.) are in fmol/g. The total number of peptides containing the glucagon sequence (=glucagon, proglucagon, glicentin and oxyntomodulin) was measured using side-viewing antiserum 4304. This antibody recognizes all fragments derived from the proglucagon precursor containing the mid-portion of glucagon (Fig. 1). Amidated GLP-1 was measured using antiserum 390, which is specific for amidated GLP-1 (Fig. 2) and does not recognise C-terminally extended forms of GLP-1 (see Materials and Methods)

\begin{tabular}{|c|c|c|c|c|}
\hline & \multicolumn{2}{|c|}{ Amidated GLP-1* } & \multicolumn{2}{|c|}{ Glucagon + proglucagon } \\
\hline & fat/fat & Wild-type & fat/fat & Wild-type \\
\hline Pancreas & $163 \pm 57$ & $1160 \pm 740$ & $66500 \pm 8600$ & $62300 \pm 8400$ \\
\hline Brain & $7 \cdot 5 \pm 1 \cdot 7$ & $33 \pm 9$ & $200 \pm 23$ & $188 \pm 15$ \\
\hline Stomach & $247 \pm 67$ & $3100 \pm 930$ & $4560 \pm 370$ & $6100 \pm 1200$ \\
\hline Intestine & $568 \pm 87$ & $3960 \pm 640$ & $18700 \pm 6400$ & $10700 \pm 2900$ \\
\hline Colon & $664 \pm 98$ & $9300 \pm 2300$ & $26300 \pm 2700$ & $30100 \pm 5400$ \\
\hline
\end{tabular}

${ }^{*} P<0 \cdot 05$.

\section{Results}

\section{Reduced concentrations of amidated GLP-1 in fat/fat mice}

The total concentrations of glucagon and proglucagon were measured using $\mathrm{Ab}$ 4304, which recognises all peptides containing the mid-glucagon sequence. We found the expected expression pattern for proglucagon: high expression in the pancreas and gut, and lower expression in the brain (Table 1). There were no significant differences in the concentrations of glucagon+ proglucagon between fat/fat and wild-type mice in any of the tissues examined (Table 1). Because of the tissuespecific processing, the fraction of amidated GLP-1 (of total glucagon-containing peptides) in tissues from wildtype mice varies from 2 to $51 \%$ (Table 2) according to the pattern shown in Fig. 1. In the pancreas, glucagon expression is so high that even though only a minor fraction $(\sim 2 \%)$ of proglucagon is processed to GLP-1, the GLP-1 concentrations amount to one-third of that observed in the small intestine.

In all fat/fat-mice tissues examined, the concentrations of amidated GLP-1 were reduced 7-14-fold) compared with those in tissue from wild-type mice (Table 1). To clarify whether this was due to altered liberation of GLP-1 or reduced amidation, we performed gel chromatography of the intestinal and pancreatic extracts (chosen to represent each of the two processing patterns) (see Fig. 1). Analysis of the brain processing pattern failed because of the small amounts of peptide present. In the pancreatic extracts of fat/fat mice, there was a minor increase in GLP-1 relative to the amount in the wild type (Fig. 3); the opposite pattern was seen in the intestinal extracts (Figs 3 and 4). However, the small changes in GLP-1 processing alone cannot explain the reduction in carboxyamidated GLP-1. We assume, therefore, that this is primarily due to a reduction amidation of GLP-1, and only to a lesser extent due to altered liberation of GLP-1 from proglucagon.

The ratio between GLP 1-36 amide/GLP1-37/38 and GLP 7-36 amide/GLP7-37/38 was unaffected by the loss of CPE, suggesting that the monobasic cleavage of GLP 1-36 amide/GLP1-37/38 to GLP 7-36 amide/GLP $7-37 / 38$ is unaffected.

Moderately attenuated processing of proglucagon by prohormone convertases in fat/fat mice

To clarify the consequences of lack of CPE on prohormone convertase processing of proglucagon in both the

Table 2 The fraction of amidated GLP-1 (GLP-1 1-36 amide+GLP-1 7-36 amide) out of the total glucagon + proglucagon in CPE-deficient fat/fat mice

GLP-1 amide, fat/fat

\begin{tabular}{lc}
\cline { 2 - 2 } & Glucagon+ proglucagon, fat/fat \\
\cline { 2 - 2 } Pancreas & $0 \cdot 25 \%$ \\
Brain & $3 \cdot 80 \%$ \\
Stomach & $5 \cdot 40 \%$ \\
Intestine & $3 \cdot 00 \%$ \\
Colon & $2 \cdot 50 \%$
\end{tabular}

GLP-1 amide, wild-type

\begin{tabular}{c}
\hline Glucagon + proglucagon, wild-type \\
\hline $2 \%$ \\
$18 \%$ \\
$51 \%$ \\
$37 \%$ \\
$31 \%$
\end{tabular}


CONTROL MICE

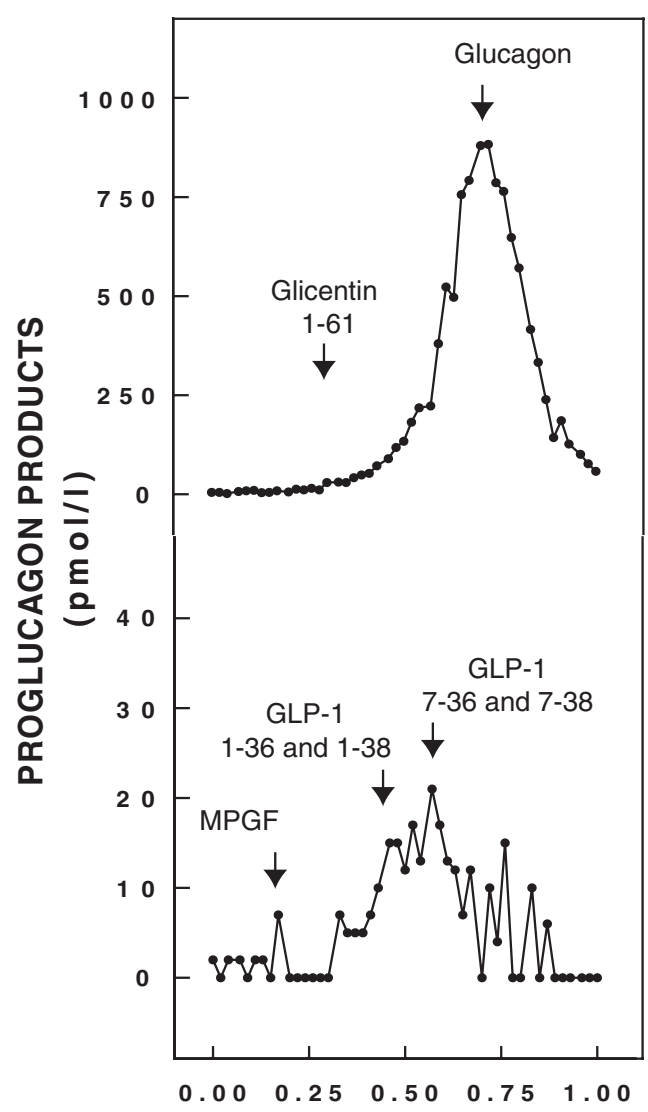

fat/fat MICE

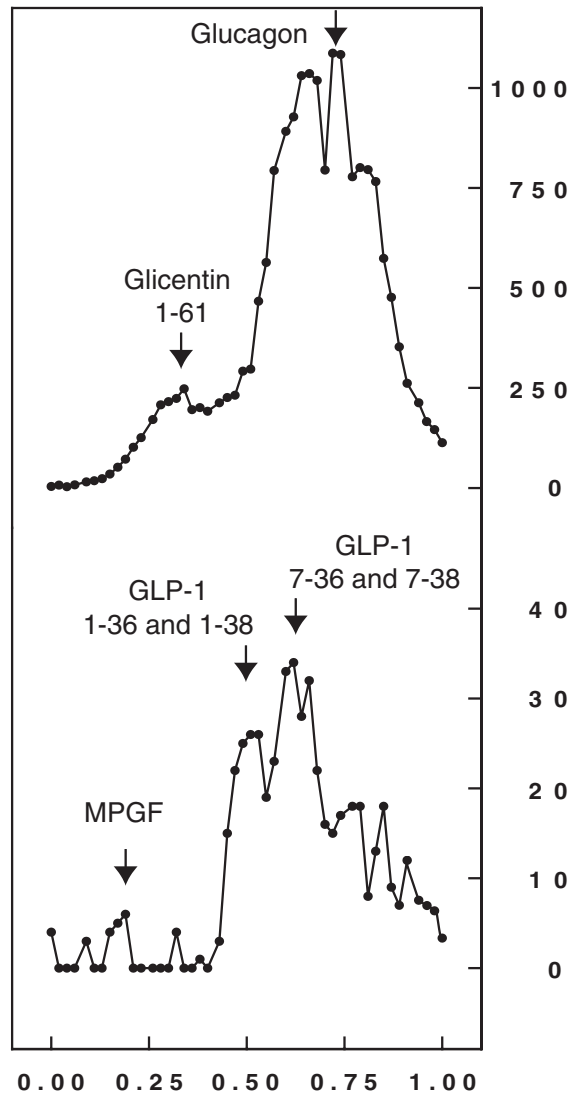

\section{ELUTION CONSTANT $\left(K_{d}\right)$}

Figure 3 Gel chromatography of pools of pancreatic extracts from fat/fat mice (right) and wild-type controls (left). The upper graphs show the elution of glucagon and glicentin and other fragments of preproglucagon containing a mid-portion of the glucagon sequence measured using antiserum 4304. The lower graphs show the elution of peptides containing the mid-portion of GLP-1 studied using the side-viewing antiserum 2135. The peaks are identified relative to elution positions of the synthetic glucagon and glicentin peptides used for calibration.

pancreas and the gut, the extracts were monitored with antibodies against the glucagon sequence. In the gel filtration from the pancreatic extracts from fat/fat mice, a peak corresponding to the elution position of glicentin 1-61 (Baldissera \& Holst 1986) was identified by using both antiserum 4304 and antiserum 4305 (data not shown); this was not present in extracts from the wild-type mice (Fig. 3). Furthermore, the intestinal processing of proglucagon was also affected, as demonstrated by a reduction in the amount of oxyntomodulin (Fig. 4). Thus, in both tissues a lack of CPE attenuated cleavage in proglucagon at the dibasic site Lys 31/Arg 32 in the fat/fat mice.
To evaluate the C-terminal removal of Lys 62 and Arg 63 from glucagon and glicentin 1-61, we monitored the elution with Ab 4305 (data not shown). As there were similar elution profiles in fat/fat and wild-type mice, we conclude that CPE is not important for the C-terminal processing of the glucagon sequence.

The attenuated carboxypeptidase processing potentially could also affect the removal of the Lys 31 and Arg 32 from GRPP, Lys 70 and Arg 71 from IP-1, and glicentin and oxyntomodulin and Arg 124 and Arg 125 from IP-2. However, as we do not have antibodies that would allow us to detect altered processing at these amino acids we are unable to investigate this possibility. 
CONTROL MICE

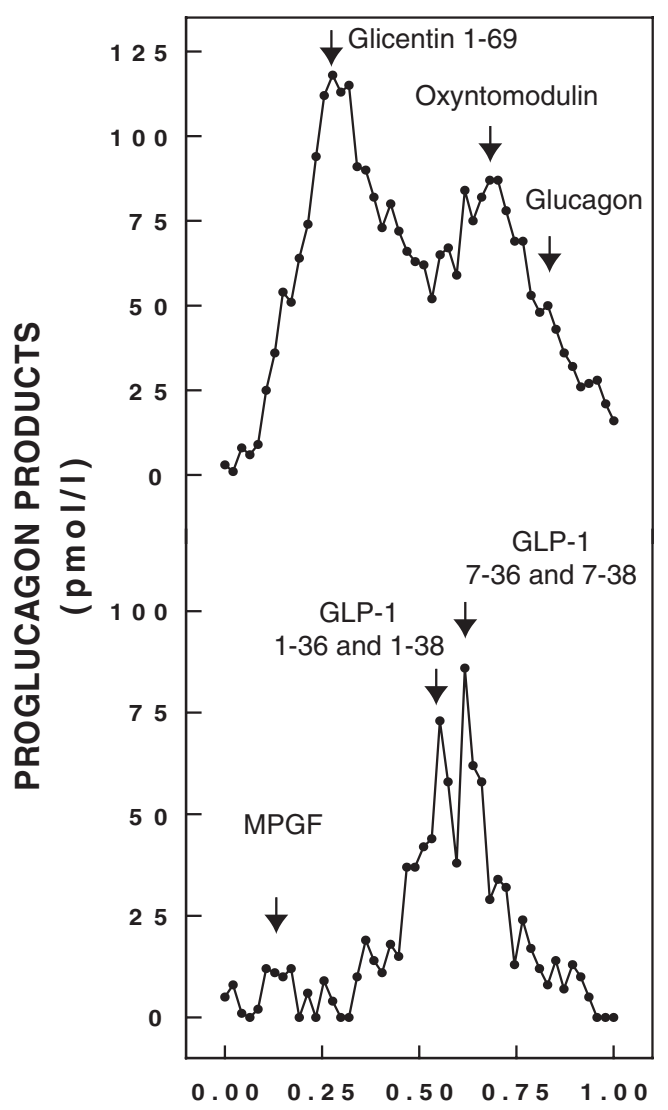

fat/fat MICE

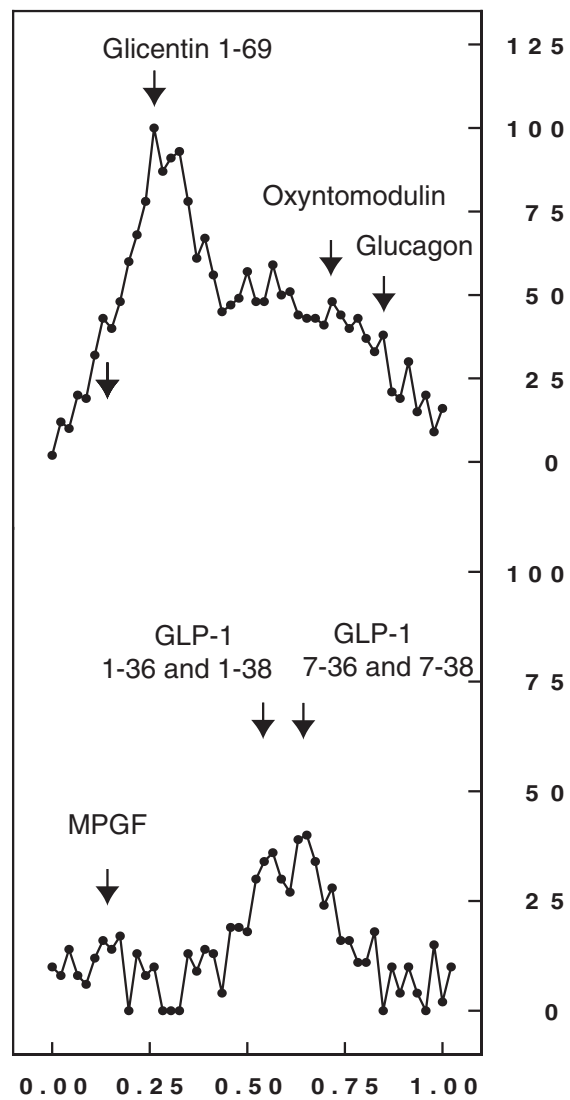

ELUTION CONSTANT

$\left(K_{d}\right)$

Figure 4 Gel chromatography of pools of small intestinal extracts from fat/fat mice (right) and wild type controls (left). The upper panels shows the elution of glucagon, oxyntomodulin and glicentin measured using antiserum 4304, that is a side viewing antibody, recognising the mid portion of glucagon. The lower panels shows the elution of peptides containing the mid portion of GLP-1 studied using the side viewing antiserum 2135. The peaks are identified relative to elution positions of the peptides used for calibration. MPGF, major proglucagon fragment.

\section{Discussion}

This study demonstrates that CPE is important for the maturation of glucagon and GLP-1. CPE is presumably the enzyme primarily responsible for the C-terminal removal of the arginyl residue from the GLP-1 peptides generated after endopeptilytic cleavage of proglucagon. Thus, GLP-1 processing follows the pattern seen for other peptide hormones studied in fat/fat mice, i.e. gastrin, CCK, insulin, melanin concentrating hormone, POMC (Naggert et al. 1995, Rovere et al. 1996, Cain et al. 1997, Lacourse et al. 1997, Udupi et al. 1997). Even though the point mutation Ser220Pro in fat/fat mice abolishes carboxypeptidase E activity, tissues from fat/fat mice still contain some amidated GLP-1, indicating the presence of other sources of carboxypeptidase activity. This has also been observed in other peptide hormone systems. Two candidates for this activity are the recently discovered carboxypeptidase D (CPD) and carboxypeptidase X $(\mathrm{CPX})$, which are present in endocrine cell lines and neurons (Dong et al. 1999, Varlamov et al. 1999a,b). However, it remains to be determined as to whether one or both account for the residual carboxypeptidase activity in the cells expressing proglucagon.

The accumulation of that which elutes as glicentin 1-61 in pancreatic extracts, and the reduced formation of that which elutes as oxyntomodulin in intestinal extracts, indicate that a lack of CPE also interferes with the 
prohormone convertase-mediated processing of the proglucagon precursor. This effect is primarily at Lys 31/Arg 32. PC2 has been shown to responsible for the dibasic at Lys 31/Arg 32 cleavage and to participate in the Lys 62/Arg 63 cleavage (Furuta et al. 1997, Westphal et al. 1999). Thus, PC2 is necessary for liberating glucagon from proglucagon. The changes in dibasic cleavage of proglucagon described here resemble - but are less pronounced than - those seen in mice lacking PC2 activity (Furuta et al. 1997, Westphal et al. 1999). This suggests that the attenuated processing is due to reduced PC2 activity in the fat/fat mice. It has been shown that processing of the inhibitory $7 \mathrm{~B} 2 \mathrm{C}$-terminal peptide by CPE greatly reduces its inhibitory potency against PC2 (Zhu et al. 1996). Hence, loss of active CPE could result in increased concentrations of the inhibitory 7B2 C-terminal peptide, which would inhibit PC2 action. This is one of the first reports to indicate that CPE activity appears to regulate PC2 activity in vivo.

A lack of CPE also mildly affected prohormone convertase processing of GLP-1, but the effects seen varied in the two tissues examined. It has been suggested that PC2 is not important for the liberation of GLP-1 (Rouille et al. 1997), but, as GLP-1 processing in the PC2 or $7 \mathrm{~B} 2$ knockouts has not been studied, we cannot tell how our observations correlate with altered PC2 activity.

The biological consequences of reduced GLP-1 amidation are not known. The bioactivity of GLP-1 is confined to the N-terminus of the GLP-1 7-36 amide, which is why C-terminal amidation is not believed to be of major importance for GLP-1 action. Both in vivo and in vitro studies have indicated that GLP-1 7-37 and GLP-1 7-36 amide have a similar potency for the GLP-1 receptor (Ørskov et al. 1993, Wettergren et al. 1998). However, there are, at present, no studies that have examined the potency of GLP-1 7-38. Since there seems to be equipotency of GLP-1 7-36 amide and GLP-1 7-37, it is likely that GLP-1 7-38 has the same bioactivity as GLP-1 7-37. Although several immunoreactive forms of GLP-1 are released in vivo, including GLP-1 7-36 amide and GLP-1 7-37, most of the GLP-1 in circulation in humans is GLP-1 7-36 amide (Ørskov et al. 1994). Carboxyamidation of GLP-1, as well as that of other hormones (e.g. gastrin), seems to protect against C-terminal degradation, and it is therefore likely that GLP-1 7-38 has a shorter half-life than GLP-1 7-36 amide, just like GLP-1 7-37 (Wettergren et al. 1998). The consequences of this could be lower GLP-1 plasma concentrations, which might contribute to the diabetic aspects of the phenotype of the fat/fat mice. The fat/fat mice have mild fasting hyperglycaemia and severe prolonged hyperglycaemia after the oral glucose tolerance test (L Friis-Hansen, unpublished observations), and the same thing is observed in mice lacking the GLP-1 receptor (Scrocchi et al. 1996).

It is unclear as to whether incomplete cerebral GLP-1 processing also contributes to the obesity phenotype of the fat/fat mouse. The GLP-1-receptor knockout mice are not obese, nor do they display disturbances in food intake. However, unlike the GLP-1-receptor-deficient mice, the fat/fat mice have multihormone disturbances, and the defects in the proglucagon processing therefore act in concert with other neuroendocrine defects. In future, the contribution of different hormone systems to the diabetic and obesity phenotype of the fat/fat mouse could be addressed by studies using cell-type-specific rescue of CPE in this animal model.

\section{Acknowledgements}

We thank Lene Albæk for technical assistance. This work was supported by the Danish MRC (L F-H and J J H), Novo Nordisk (L F-H) and the National Institutes of Health (L C S and K A L).

\section{References}

Baldissera FGA \& Holst JJ 1986 Glicentin 1-61 probably represents a major fraction of glucagon related peptides in plasma of anaesthetized uraemic pigs. Diabetologica 29 462-467.

Cain BM, Wang W \& Beinfeld MC 1997 Cholecystokinin (CCK) levels are greatly reduced in the brains but not the duodenum of $\mathrm{CPE}^{\mathrm{fat}} / \mathrm{CPE}^{\mathrm{fat}}$ mice: a regional difference in the involvement of carboxypeptidase E (CPE) in pro-CCK processing. Endocrinology 138 4034-4037.

Cool DR, Normant E, Shen F-S, Chen H-C, Pannell L, Zhang Y \& Loh YP 1997 Carboxypeptidase E is a regulated secretory pathway sorting receptor: genetic obliteration leads to endocrine disorders in $\mathrm{CPE}^{\mathrm{fat}}$ mice. Cell 88 73-83.

Dong W, Fricker LD \& Day R 1999 Carboxypeptidase D is a potential candidate to carry out redundant processing functions of carboxypeptidase $\mathrm{E}$ based on comparative distribution studies in rat central nervous system. Neuroscience 89 1301-1317.

Drucker DJ, Erlich P, Asa SL \& Brubaker PL 1996 Induction of intestinal epithelial proliferation by glucagon-like peptide 2. PNAS 93 7911-7916.

Furuta M, Yano H, Zhou A, Rouille Y, Holst JJ, Carroll R, Ravazzola M, Orci L, Furuta H \& Steiner DF 1997 Defective prohormone processing and altered pancreatic islet morphology in mice lacking active SPC2. PNAS 94 6646-6651.

Holst JJ 1982 Evidence that enteroglucagon (II) is identical with the C-terminal sequence (residues 33-39) of glicentin. Biochemical Journal 207 381-388.

Holst JJ 1997 Posttranslational processing of proglucagon and postsecretory fate of proglucagon products. In The Insulinotropic Gut Hormone Glucagon-like Peptide 1, pp 24-48. Eds HC Fehman \& B Göke. Basle: Kärger.

Lacourse KA, Friis-Hansen L, Rehfeld JF \& Samuelson LC 1997 Disturbed progastrin processing in the carboxypeptidase E deficient fat mouse. FEBS Letters 416 45-50.

Lacourse KA, Friis-Hansen L, Samuelson LC \& Rehfeld JF 1998 Altered processing of procholecystokin processing in carboxypeptidase E-deficient fat mice: differential synthesis in neurons and endocrine cells. FEBS Letters 436 61-66.

Miller SA, Dykes DD \& Polesky HF 1988 A simple salting out procedure for extracting DNA from human nucleated cells. Nucleic Acids Research 161215.

Naggert JK, Fricker LD, Varlamov O, Nishina PM, Rouille Y, Steiner DF, Carroll RJ, Paigen BJ \& Leiter EH 1995 
Hyperproinsulinaemia in obese fat/fat mice associated with a carboxypeptidase E mutation which reduces enzyme activity. Nature Genetics 10 135-142.

Normant E \& Loh YP 1998 Depletion of carboxypeptidase E, a regulated secretory pathway sorting receptor, causes misrouting and constitutive secretion of proinsulin and proenkephalin, but not chromogranin A. Endocrinology 139 2137-2145.

Ørskov C, Jeppesen J, Madsbad S \& Holst JJ 1991 Proglucagon products in plasma of non-insulin dependent diabetics and nondiabetic controls in the fasting state and following oral glucose and intravenous arginine. Journal of Clinical Investigation 87 415-423.

Ørskov C, Wettergren A \& Holst JJ 1993 Biological effects and metabolic rates of glucagonlike peptide-1 7-36 amide and glucagonlike peptide-1 7-37 in healthy subjects are indistinguishable. Diabetes 42 658-661.

Ørskov C, Rabenhøj L, Wettergren A, Kofod H \& Holst JJ 1994 Tissue and plasma concentrations of amidated and glycine-extended glucagon-like peptide I in humans. Diabetes 43 535-539.

Perloff MD, Kream RM \& Beinfeld MC 1998 Reduced levels of substance $\mathrm{P}$ in the brains of $\mathrm{Cpe}^{\mathrm{fat}} / \mathrm{Cpe}^{\mathrm{fat}}$ mice. Peptides 19 1115-1117.

Rindler MJ 1998 Carboxypeptidase E, a peripheral membrane protein implicated in the targeting of hormones to secretory granules, co-aggregates with granule content proteins at acidic $\mathrm{pH}$. Journal of Biological Chemistry 273 31180-31185.

Rouille Y, Martin S \& Steiner DF 1995 Differential processing of proglucagon by the subtilisin-like prohormone convertases PC2 and PC3 to generate either glucagon or glucagon-like peptide. Journal of Biological Chemistry 270 26488-26496.

Rouille Y, Kantengwa S, Irminger JC \& Halban PA 1997 Role of the prohormone convertase PC3 in the processing of proglucagon to glucagon-like peptide 1. Journal of Biological Chemistry 272 32810-32816.

Rovere C, Viale A, Nahon J-L \& Kitabgi P 1996 Impaired processing of brain proneurotensin and promelanin-concentrating hormone in obese fat/fat mice. Endocrinology 137 2954-2958.

Scrocchi LA, Brown TJ, Maclusky N, Brubaker PL, Auerbach AB, Joyner AL \& Drucker DJ 1996 Glucose intolerance but normal satiety in mice with a null mutation in the glucagon-like peptide 1 receptor. Nature Medicine 2 1254-1258.

Tang-Christensen M, Larsen PJ, Goke R, Fink-Jensen A, Jessop DS, Moller M \& Sheikh SP 1996 Central administration of
GLP-1-(7-36) amide inhibits food and water intake in rats. American Journal of Physiology 271 R848-R856.

Turton MD, O'Shea D, Gunn I, Beak SA, Edwards CM, Meeran K, Choi SJ, Taylor GM, Heath MM, Lambert PD, Wilding JP, Smith DM, Ghatei MA, Herbert J \& Bloom SR 1996 A role for glucagon-like peptide-1 in the central regulation of feeding. Nature 379 69-72.

Udupi V, Gomez P, Song L, Varlamov O, Reed JT, Leiter EH, Fricker LD \& Greeley GH 1997 Effect of carboxypeptidase E deficiency on progastrin processing and gastrin messenger ribonucleic acid expression in mice with the fat mutation. Endocrinology 138 1959-1963.

Varlamov O, Fricker LD, Furukawa H, Steiner DF, Langley SH \& Leiter EH 1997 -cell lines derived from transgenic Cpe $e^{\text {fat }} / C p e^{\text {fat }}$ mice are defective in carboxypeptidase $\mathrm{E}$ and proinsulin processing. Endocrinology 138 4883-4892.

Varlamov O, Eng FJ, Novikova EG \& Fricker LD 1999a Localization of metallocarboxypeptidase D in AtT-20 cells. Potential role in prohormone processing. Journal of Biological Chemistry 274 14759-14767.

Varlamov O, Wu F, Shields D \& Fricker LD $1999 b$ Biosynthesis and packaging of carboxypeptidase D in nascent secretory granules in pituitary cell lines. Journal of Biological Chemistry 274 14040-14045.

Westphal CH, Muller L, Zhou A, Zhu X, Bonner-Weir S, Schambelan M, Steiner DF, Lindberg I \& Leder P 1999 The neuroendocrine protein $7 \mathrm{~B} 2$ is required for peptide hormone processing in vivo and provides a novel mechanism for pituitary Cushing's disease. Cell 96 689-700.

Wettergren A, Pridal L, Wøjdemann M \& Holst JJ 1998 Amidated and non amidated gluagon like peptide-1 (GLP-1): non pancreatic effects (cephalic phase acid secretion) and stability in human plasma. Regulatory Peptides 77 83-88.

Zhu X, Rouille Y, Lamango NS, Steiner DF \& Lindberg I 1996 Internal cleavage of the inhibitory 7B2 carboxyl-terminal peptide by PC2: a potential mechanism for its inactivation. PNAS $\mathbf{9 3}$ 4919-4924.

Received in final form 11 January 2001

Accepted 31 January 2001 